\title{
Effect of Integrated Nitrogen Management on Macronutrient Content in Toria (Brassica campestris L.var.M-27)
}

\author{
Wangkhem Herojit Meetei* , RK. Kumarjit Singh, A. Herojit Singh, \\ N. Surbala Devi, L. Nabachandra Singh and N. Gopimohan Singh
}
Department of Soil Science and Agricultural Chemistry, College of Agriculture, Central Agricultural University, Imphal-795004, Manipur, India
*Corresponding author

\section{A B S T R A C T}

\begin{tabular}{|l|}
\hline Ke y w o r d s \\
Toria, \\
vermicompost, \\
Azotobacter, \\
Integrated nitrogen \\
management, \\
Nutrient content \\
\hline Article Info \\
\hline $\begin{array}{l}\text { Accepted: } \\
\text { 04 October } 2020 \\
\text { Available Online: } \\
\text { 10 November } 2020\end{array}$ \\
\hline
\end{tabular}

\section{Introduction}

Among the oilseeds, rapeseed (Brassica campestris L. var. M-27) is one of the important oilseed crops grown in Rabi season contributing $25 \%$ of the oilseed production of the country (Chidda Singh, 1983). India holds a premier position in rapeseed - mustard economy of the world with third rank in both area and production (Rai et al., 2016). Important of oilseeds, asa source of both fat and protein is well known. The oil content of rapeseed- mustard seed ranges from 30-47 \% and $20-40 \%$ protein. It accounts for $19 \%$ of world's area and $9 \%$ of the global production (Sinha, 2003). In Manipur, rapeseed occupies an area of 37.67 thousand ha with an annual production of 32.78 thousand $\mathrm{Mt}$ and productivity of $0.87 \mathrm{Mt} \mathrm{ha}{ }^{-1}$ (Anonymous, 2017-18). Rapeseed is grown entirely as a rainfed crop due to non - availability of irrigation facilities in Manipur. Enhancement of the productivity of rapeseed - mustard can be achieved by the use of balanced fertilization by application of nitrogen through organic and inorganic manures is of 
great significance, so as to attain maximum economic yield without any deleterious effect on soil properties or ecological balance.

Analysis of plant sample is an important component of soil fertility evaluation and plant nutrition research. It has been used as a diagnostic technique for assessing deficiency and toxicity of nutrients in plants. It is also used for determining the nutrient status and fertilizer needs. Maintenance of soil fertility for sustainable production requires replenishment of nutrient elements removed by crops through application of fertilizer. Balanced use of nutrients is one of the most important factor for sustaining rice production and soil health.

The results emanating from long-term fertilizer experiments have clearly indicated that imbalance use of chemical fertilizers has resulted in numerous problems viz. micronutrient deficiencies, nutrient imbalances in soil and plant system, depletion of soil fertility, environmental degradation and deterioration of soil health (Kimmo, 1993). A fertile soil will contain all the major nutrients for basic plant nutrition ( $\mathrm{N}, \mathrm{P}$ and $\mathrm{K}$ ) as well as other nutrients needed in smaller quantities ( $\mathrm{Ca}, \mathrm{Mg}, \mathrm{S}, \mathrm{Fe}, \mathrm{Zn}, \mathrm{Cu}, \mathrm{B}, \mathrm{Mn}$, etc.). Usually, a fertile soil will also have some organic matter that improves soil structure, soil moisture retention, nutrient retention and a $\mathrm{pH}$ of $6-7$. Unfortunately, soils that do not have adequate levels of all the necessary plant nutrients, or conditions in the soil are unfavourable for plant uptake of certain nutrients. It is; therefore, appropriate to develop a sustainable crop production technology which is cheaper, locally available, socially acceptable and environmentally sound vis-à-vis maintains soil health. Such a scenario can be retrieved through integration of chemical fertilizers with available organic sources of plant nutrients. Integrated nutrient management
(INM) aims to improve soil health and sustain high level of productivity and production (Prasad et al., 1995) Latha et al., (2019) reported increased in $\mathrm{N}, \mathrm{P}$ and $\mathrm{K}$ contents in toria with the application of organics as well as inorganic fertilizers. Organics supply nutrients at the peak period of absorption, and also provide micro nutrients and modify soilphysical behaviour as well as increase the efficiency of applied nutrients (Pandey et al., 2007). Keeping this in view, an investigation was undertaken to study the effect of integrated nutrient management on macronutrient content in toria.

\section{Materials and Methods}

A field experiment was undertaken at Research Farm of College of Agriculture, Central Agricultural University, Imphal during two consecutive years of 2015-16 and 2016-17. The experimental site was situated at $24^{0} 48^{\prime} 44.50^{\prime \prime} \mathrm{N}$ latitude, $93^{0} 53^{\prime} 29.98^{\prime \prime} \mathrm{E}$ longitude and altitude of $790 \mathrm{~m}$ above mean sea level. It comes under the Eastern Himalayan Region (II) and the agro-climatic zone Sub-Tropical Zone (NEH-4) of Manipur (Experimental Agro met Advisory Service ICAR Complex for NEH Region, Manipur Centre, Lamphelphet, Imphal). Imphal valley enjoys sub-tropical climate with an average annual rainfall of about $1467.5 \mathrm{~mm}$. Monsoon rain start from the month of June and continues up to October with pre-monsoon showers from March onward. During the experimentation periods, the mean maximum and minimum temperatures lies between $27.8^{\circ} \mathrm{C}$ and $4.6^{\circ} \mathrm{C}$.

The relevant physicochemical properties of the soil were presented in Table 1. Soil texture, water holding capacity (WHC), $\mathrm{pH}$, EC, organic carbon, cation exchange capacity (CEC), available N, P and $\mathrm{K}$ were determined following the standard procedure described by Jackson (1973). The experiment was laid out 
in Randomised Block Design with twelve treatments replicated thrice. The treatments were applied to rapeseed (Toriavar.M-27).

The treatments used in the study were $\mathrm{T}_{0^{-}}$ control, $\mathrm{T}_{1^{-}} 100 \%$ RDN using chemical fertilizer Urea, $\mathrm{T}_{2}-100 \%$ using Vermicompost as N-source, $\mathrm{T}_{3}-100 \%$ using Azolla as Nsource + Azotobacter, $\mathrm{T}_{4}-75 \% \mathrm{RDN}$ using Urea $+25 \%$ RDN using Vermicompost, $\mathrm{T}_{5^{-}}$ $75 \%$ RDN using (Urea) $+25 \%$ using Azolla + Azotobacter, $\mathrm{T}_{6}-50 \%$ RDN using Urea $+50 \%$ RDN using Vermicompost, $\mathrm{T}_{7}-50 \%$ RDN using Urea $+50 \%$ using Azolla + Azotobacter, $\mathrm{T}_{8}-25 \%$ RDN using Urea $+75 \%$ RDN using Vermicompost, $\mathrm{T}_{9}-25 \%$ RDN using Urea $+75 \%$ using Azolla + Azotobacter, $\quad \mathrm{T}_{10}-100 \% \quad \mathrm{RDN}$ using Vermicompost $+100 \%$ using Azolla + Azotobacter, $\mathrm{T}_{11^{-}} 100 \%$ RDN using chemical fertilizer $+100 \%$ RDN using Vermicompost $+100 \%$ using Azolla + Azotobacter.

Application of fertilizer was made as per treatment.The recommended dose of fertilizer for toria was 40:30:20 kg N, $\mathrm{P}_{2} \mathrm{O}_{5}$ and $\mathrm{K}_{2} \mathrm{O}$ per ha respectively. Full dose of phosphorus $\left(\mathrm{P}_{2} \mathrm{O}_{5}\right)$, potassium $\left(\mathrm{K}_{2} \mathrm{O}\right)$ and half dose of nitrogen $(\mathrm{N})$ as urea were applied as basal application a day before the date of sowing in the form of urea, single super phosphate (SSP) and muriate of potash (MOP), respectively. The vermicompost was thoroughly mixed in soil as per treatment after final ploughing. The remaining dose of nitrogen was top dressed at pre -flowering stage. Azolla was collected from the surrounding area and made dried in shade.In the meantime, dried Azolla @ 1.16 tonnes ha ${ }^{1}, 0.87$ tonnes $\mathrm{ha}^{-1}, 0.58$ tonnes $\mathrm{ha}^{-1}$ and 0.29 tonnes ha ${ }^{-1}$ equivalent to $40 \mathrm{~kg} \mathrm{~N} \mathrm{ha}^{-1}(100 \%$ RDN), $30 \mathrm{~kg} \mathrm{~N} \mathrm{ha}^{-1}$ (75\% RDN), $20 \mathrm{~kg} \mathrm{~N} \mathrm{ha}^{-1}$ (50\% RDN) and $10 \mathrm{~kg} \mathrm{~N} \mathrm{ha}^{-1}(25 \% \mathrm{RDN})$ were applied according to different sets of treatment. Again, properly clean seeds were used for seed treatment in rapeseed. Gur slurry was prepared and poured on seed. Azotobacter@20 $\mathrm{g} \mathrm{kg}^{-1}$ seeds was added and mixed by hand till the seeds were uniformly coated except control. The treated seeds were dried in shade and sown immediately.

Plant samples were periodically collected randomly at $30^{\text {th }}, 60^{\text {th }}$, and $90^{\text {th }}$ days after sowing (DAS) and at the time of harvest. Samples were washed properly, then, dried at $65^{\circ}$ Cfor 72 hours, powdered and kept for analysis of macronutrient ( $\mathrm{N}, \mathrm{P}$ and $\mathrm{K}$ ) content. Total $\mathrm{N}$ content was estimated using the modified micro kjeldahl method as described by Jackson (1973). Di-acid $\left(\mathrm{HNO}_{3}\right.$ : $\left.\mathrm{HClO}_{4}\right)$ extracts of plant samples were subjected to analysis of $\mathrm{P}$ using the vanadomolybdate phosphoric acid yellow colour (Ammonium molybdate + ammonium metavanadate) method and total potassium was determined flame photometrically from the same extract Jackson (1973).

\section{Results and Discussion}

\section{Nitrogen $(\mathbf{N})$ content}

Data on effect of nitrogen content in toria at different growth stages are shown in Table 2. Result revealed that $\mathrm{N}$ content in both the years of the experiment followed similar patterns. An increase in $\mathrm{N}$ content was noticed at $60^{\text {th }}$ DAS followed by a decreasing trend till the harvest stage. However, in the second year higher $\mathrm{N}$ content was observed in all the sampling days as compared to first year. Irrespective of different crop growth, significantly higher $\mathrm{N}$ concentration was observed in both the years over the control. Pooled data also showed the same trend of nitrogen accumulation at different stages. Irrespective of different sampling days and year of the study, application of inorganic or organic sources of nitrogen either singly or in combination significantly increased the nitrogen concentration in crop over untreated 
control. This is corroborated with the findings of Nehra and Grewal (2001); Jana et al., (2008); Sharif et al., (2004); Sarir et al., (2005); Davari et al., (2012); Bairwa and Yadav (2017).and Nongmeikapam and Devi (2018). Further study of the pooled data revealed that concentration of $\mathrm{N}$ in soil applied with $\mathrm{T}_{4}, \mathrm{~T}_{6}, \mathrm{~T}_{7}, \mathrm{~T}_{8}, \mathrm{~T}_{9}, \mathrm{~T}_{11}$, respectively were at par at different stages of crop growth. However, on $60^{\text {th }}$ DAS soil treated with different $\mathrm{N}$ treatments observed non-significantly difference among them.

Table.1 Initial soil characteristics of the experimental field

\begin{tabular}{|c|c|}
\hline Soil characteristics & Results \\
\hline Textural class & $\begin{array}{c}\text { Clayey } \\
\text { soil }\end{array}$ \\
\hline Sand $(\%)$ & 8.24 \\
\hline Silt $(\%)$ & 13.44 \\
\hline Clay $(\%)$ & 78.32 \\
\hline pH (1:2.5 soil : water ratio) & 5.40 \\
\hline EC $\left(1: 2.5\right.$ soil : water ratio, $\left.\mathrm{dsm}^{-1}\right)$ & 0.28 \\
\hline $\operatorname{CEC}\left[\operatorname{cmol}\left(p^{+}\right) \mathrm{kg}^{-1}\right]$ & 34.05 \\
\hline Organic carbon (\%) & 1.56 \\
\hline Available Nitrogen $\left(\mathrm{Kg} \mathrm{N} \mathrm{ha}^{-1}\right)$ & 389.39 \\
\hline Available Phosphorus $\left(\mathrm{Kg} \mathrm{P}_{2} \mathrm{O}_{5} \mathrm{ha}^{-1}\right)$ & 57.71 \\
\hline Available potassium $\left(\mathrm{Kg} \mathrm{K}_{2} \mathrm{O} \mathrm{ha}^{-1}\right)$ & 252.67 \\
\hline
\end{tabular}

Table.2 Effect of integrated nitrogen management on $\mathrm{N}$ content (\%) at different stages of toria

\begin{tabular}{|c|c|c|c|c|c|c|c|c|c|c|c|c|}
\hline \multirow[t]{2}{*}{ Treatments } & \multicolumn{3}{|c|}{30 DAS } & \multicolumn{3}{|c|}{ 60DAS } & \multicolumn{3}{|c|}{ 90DAS } & \multicolumn{3}{|c|}{ At harvest } \\
\hline & 2015-16 & $\begin{array}{l}\text { 2016- } \\
17\end{array}$ & Pooled & $\begin{array}{l}2015- \\
16\end{array}$ & $\begin{array}{l}\text { 2016- } \\
17\end{array}$ & $\begin{array}{l}\text { Poole } \\
\text { d }\end{array}$ & $\begin{array}{l}2015- \\
16\end{array}$ & $\begin{array}{l}\text { 2016- } \\
17\end{array}$ & Pooled & $\begin{array}{l}2015- \\
16\end{array}$ & $\begin{array}{l}\text { 2016- } \\
17\end{array}$ & $\begin{array}{l}\text { Poole } \\
\text { d }\end{array}$ \\
\hline $\mathbf{T}_{0}$ & 0.98 & 1.08 & 1.03 & 1.04 & 1.10 & 1.07 & 0.94 & 0.95 & 0.94 & 0.80 & 0.87 & 0.84 \\
\hline $\mathbf{T}_{1}$ & 1.15 & 1.38 & 1.27 & 1.17 & 1.41 & 1.29 & 1.03 & 1.15 & 1.09 & 0.89 & 0.98 & 0.94 \\
\hline $\mathbf{T}_{2}$ & 1.11 & 1.35 & 1.23 & 1.16 & 1.36 & 1.26 & 1.03 & 1.14 & 1.09 & 0.89 & 0.99 & 0.94 \\
\hline $\mathbf{T}_{3}$ & 1.09 & 1.34 & 1.21 & 1.15 & 1.35 & 1.25 & 1.02 & 1.09 & 1.06 & 0.89 & 0.98 & 0.93 \\
\hline $\mathbf{T}_{4}$ & 1.15 & 1.39 & 1.27 & 1.17 & 1.45 & 1.31 & 1.04 & 1.18 & 1.11 & 0.92 & 0.99 & 0.96 \\
\hline $\mathbf{T}_{5}$ & 1.14 & 1.37 & 1.26 & 1.16 & 1.43 & 1.30 & 1.04 & 1.17 & 1.10 & 0.91 & 0.98 & 0.95 \\
\hline$T_{6}$ & 1.15 & 1.38 & 1.27 & 1.17 & 1.44 & 1.30 & 1.04 & 1.18 & 1.11 & 0.91 & 0.98 & 0.95 \\
\hline $\mathbf{T}_{7}$ & 1.14 & 1.35 & 1.24 & 1.16 & 1.40 & 1.28 & 1.04 & 1.15 & 1.09 & 0.90 & 0.99 & 0.94 \\
\hline $\mathbf{T}_{8}$ & 1.17 & 1.41 & 1.29 & 1.19 & 1.48 & 1.33 & 1.06 & 1.20 & 1.13 & 0.93 & 0.99 & 0.96 \\
\hline $\mathbf{T}_{9}$ & 1.12 & 1.38 & 1.25 & 1.17 & 1.43 & 1.30 & 1.04 & 1.17 & 1.11 & 0.91 & 0.99 & 0.95 \\
\hline $\mathbf{T}_{10}$ & 1.11 & 1.35 & 1.23 & 1.16 & 1.40 & 1.28 & 1.03 & 1.15 & 1.09 & 0.90 & 0.98 & 0.94 \\
\hline$T_{11}$ & 1.16 & 1.40 & 1.28 & 1.17 & 1.46 & 1.32 & 1.05 & 1.20 & 1.12 & 0.92 & 0.99 & 0.96 \\
\hline $\mathrm{SE}(\mathrm{d}) \pm$ & 0.022 & 0.027 & 0.029 & 0.023 & 0.027 & 0.046 & 0.020 & 0.022 & 0.026 & 0.018 & 0.019 & 0.012 \\
\hline $\mathrm{CD}\left({ }_{\mathrm{P}}=0.5\right)$ & 0.046 & 0.055 & 0.064 & 0.048 & 0.057 & 0.101 & 0.042 & 0.047 & 0.058 & 0.037 & 0.040 & 0.024 \\
\hline
\end{tabular}


Table.3 Effect of integrated nitrogen management on P content (\%) at different stages of toria

\begin{tabular}{|c|c|c|c|c|c|c|c|c|c|c|c|c|}
\hline \multirow[t]{2}{*}{ Treatments } & \multicolumn{3}{|c|}{30 DAS } & \multicolumn{3}{|c|}{ 60DAS } & \multicolumn{3}{|c|}{ 90DAS } & \multicolumn{3}{|c|}{ At harvest } \\
\hline & $\begin{array}{l}2015- \\
16\end{array}$ & $\begin{array}{l}\text { 2016- } \\
17\end{array}$ & $\begin{array}{l}\text { Poole } \\
\text { d }\end{array}$ & $\begin{array}{l}2015- \\
16\end{array}$ & 2016-17 & $\begin{array}{l}\text { Poole } \\
\text { d }\end{array}$ & $\begin{array}{l}2015- \\
16\end{array}$ & $\begin{array}{l}2016- \\
17\end{array}$ & $\begin{array}{l}\text { Poole } \\
\text { d }\end{array}$ & $\begin{array}{l}2015- \\
16\end{array}$ & $\begin{array}{l}\text { 2016- } \\
17\end{array}$ & $\begin{array}{l}\text { Poole } \\
\text { d }\end{array}$ \\
\hline $\mathbf{T}_{0}$ & 0.350 & 0.390 & 0.370 & 0.330 & 0.373 & 0.352 & 0.323 & 0.350 & 0.337 & 0.290 & 0.310 & 0.300 \\
\hline$T_{1}$ & 0.410 & 0.410 & 0.410 & 0.393 & 0.393 & 0.393 & 0.389 & 0.390 & 0.390 & 0.360 & 0.360 & 0.360 \\
\hline $\mathbf{T}_{2}$ & 0.410 & 0.420 & 0.415 & 0.395 & 0.403 & 0.399 & 0.393 & 0.385 & 0.389 & 0.370 & 0.370 & 0.370 \\
\hline $\mathbf{T}_{3}$ & 0.390 & 0.410 & 0.400 & 0.380 & 0.393 & 0.387 & 0.373 & 0.385 & 0.379 & 0.350 & 0.360 & 0.355 \\
\hline $\mathbf{T}_{4}$ & 0.430 & 0.430 & 0.430 & 0.410 & 0.413 & 0.412 & 0.405 & 0.400 & 0.403 & 0.380 & 0.380 & 0.380 \\
\hline $\mathbf{T}_{5}$ & 0.420 & 0.420 & 0.420 & 0.395 & 0.403 & 0.399 & 0.403 & 0.395 & 0.399 & 0.380 & 0.370 & 0.375 \\
\hline $\mathbf{T}_{6}$ & 0.420 & 0.430 & 0.425 & 0.405 & 0.413 & 0.409 & 0.403 & 0.405 & 0.404 & 0.380 & 0.370 & 0.375 \\
\hline $\mathbf{T}_{7}$ & 0.410 & 0.420 & 0.415 & 0.395 & 0.403 & 0.399 & 0.393 & 0.395 & 0.394 & 0.372 & 0.370 & 0.371 \\
\hline $\mathbf{T}_{8}$ & 0.440 & 0.430 & 0.435 & 0.423 & 0.413 & 0.418 & 0.420 & 0.410 & 0.415 & 0.400 & 0.390 & 0.395 \\
\hline$T_{9}$ & 0.410 & 0.410 & 0.410 & 0.395 & 0.395 & 0.395 & 0.393 & 0.393 & 0.393 & 0.360 & 0.370 & 0.365 \\
\hline$T_{10}$ & 0.410 & 0.420 & 0.415 & 0.395 & 0.403 & 0.399 & 0.393 & 0.390 & 0.392 & 0.380 & 0.360 & 0.370 \\
\hline$T_{11}$ & 0.440 & 0.430 & 0.435 & 0.423 & 0.413 & 0.418 & 0.413 & 0.405 & 0.409 & 0.390 & 0.380 & 0.385 \\
\hline $\mathrm{SE}(\mathrm{d}) \pm$ & 0.008 & 0.009 & 0.010 & 0.008 & 0.008 & 0.010 & 0.007 & 0.008 & 0.006 & 0.007 & 0.007 & 0.008 \\
\hline $\mathrm{CD}\left({ }_{\mathrm{P}}=0.5\right)$ & 0.017 & 0.019 & 0.021 & 0.016 & 0.017 & 0.021 & 0.015 & 0.016 & 0.012 & 0.015 & 0.016 & 0.017 \\
\hline
\end{tabular}

Table.4 Effect of integrated nitrogen management on $\mathrm{K}$ content $(\%)$ at different stages of toria

\begin{tabular}{|c|c|c|c|c|c|c|c|c|c|c|c|c|}
\hline \multirow[t]{2}{*}{ Treatments } & \multicolumn{3}{|c|}{30 DAS } & \multicolumn{3}{|c|}{ 60DAS } & \multicolumn{3}{|c|}{ 90DAS } & \multicolumn{3}{|c|}{ At harvest } \\
\hline & $\begin{array}{l}2015- \\
16\end{array}$ & $\begin{array}{l}2016- \\
17\end{array}$ & $\begin{array}{l}\text { Poole } \\
\text { d }\end{array}$ & $\begin{array}{l}2015- \\
16\end{array}$ & $\begin{array}{l}\text { 2016- } \\
17\end{array}$ & $\begin{array}{l}\text { Poole } \\
\text { d }\end{array}$ & $\begin{array}{l}2015- \\
16\end{array}$ & $\begin{array}{l}\text { 2016- } \\
17\end{array}$ & $\begin{array}{l}\text { Poole } \\
\text { d }\end{array}$ & $\begin{array}{l}2015- \\
16\end{array}$ & $\begin{array}{l}\text { 2016- } \\
17\end{array}$ & $\begin{array}{l}\text { Poole } \\
\text { d }\end{array}$ \\
\hline $\mathbf{T}_{0}$ & 1.19 & 1.21 & 1.20 & 1.00 & 1.01 & 1.00 & 0.80 & 0.80 & 0.80 & 0.71 & 0.73 & 0.72 \\
\hline$T_{1}$ & 1.31 & 1.44 & 1.38 & 1.08 & 1.18 & 1.13 & 0.86 & 0.90 & 0.88 & 0.80 & 0.85 & 0.83 \\
\hline $\mathbf{T}_{2}$ & 1.32 & 1.42 & 1.37 & 1.09 & 1.18 & 1.13 & 0.85 & 0.90 & 0.88 & 0.81 & 0.88 & 0.85 \\
\hline $\mathbf{T}_{3}$ & 1.30 & 1.43 & 1.37 & 1.07 & 1.16 & 1.11 & 0.85 & 0.90 & 0.87 & 0.80 & 0.86 & 0.83 \\
\hline $\mathbf{T}_{4}$ & 1.33 & 1.45 & 1.39 & 1.10 & 1.20 & 1.15 & 0.88 & 0.96 & 0.92 & 0.83 & 0.92 & 0.88 \\
\hline $\mathbf{T}_{5}$ & 1.31 & 1.44 & 1.38 & 1.08 & 1.15 & 1.11 & 0.86 & 0.93 & 0.89 & 0.81 & 0.89 & 0.85 \\
\hline$T_{6}$ & 1.32 & 1.45 & 1.39 & 1.09 & 1.20 & 1.14 & 0.87 & 0.94 & 0.90 & 0.82 & 0.91 & 0.87 \\
\hline $\mathbf{T}_{7}$ & 1.32 & 1.44 & 1.38 & 1.08 & 1.18 & 1.13 & 0.86 & 0.91 & 0.89 & 0.81 & 0.87 & 0.84 \\
\hline $\mathbf{T}_{8}$ & 1.34 & 1.47 & 1.41 & 1.11 & 1.21 & 1.16 & 0.89 & 0.97 & 0.93 & 0.84 & 0.92 & 0.88 \\
\hline$T_{9}$ & 1.31 & 1.45 & 1.38 & 1.07 & 1.17 & 1.12 & 0.87 & 0.91 & 0.89 & 0.80 & 0.86 & 0.83 \\
\hline $\mathbf{T}_{10}$ & 1.30 & 1.43 & 1.37 & 1.07 & 1.17 & 1.12 & 0.86 & 0.91 & 0.89 & 0.81 & 0.87 & 0.84 \\
\hline$T_{11}$ & 1.33 & 1.46 & 1.40 & 1.10 & 1.20 & 1.15 & 0.88 & 0.97 & 0.92 & 0.83 & 0.92 & 0.88 \\
\hline $\operatorname{SE}(d) \pm$ & 0.026 & 0.028 & 0.023 & 0.021 & 0.023 & 0.020 & 0.017 & 0.018 & 0.017 & 0.016 & 0.017 & 0.013 \\
\hline $\mathrm{CD}(\mathrm{p}=0.5)$ & 0.054 & 0.059 & 0.050 & 0.044 & 0.048 & 0.044 & 0.035 & 0.037 & 0.038 & 0.033 & 0.036 & 0.025 \\
\hline
\end{tabular}

\section{Phosphorus (P) content}

Data in relation to phosphorus content in toria at different stages are presented in Table 3. Result revealed that a decreasing trend in $\mathrm{P}$ content was observed with increase in crop age in both the years and pooled data. Reports on decline in $\mathrm{P}$ concentration with crop age were given by Liu and Zhu (1996) and Latha et al., (2019). The decrease of $\mathrm{P}$ content with the advancement of crop age might be due to three reasons: dilution effect, caused by 
higher dry matter production and fixation of native and applied phosphorus. Study of the pooled data revealed that significantly higher $P$ content was recorded in inorganic and organic sources applied singly or in combination over untreated control. Similar findings on higher concentration of phosphorus in either inorganic or organic treated soil or both were presented earlier by Nehra and Grewal (2001); Chaudhary et al., (2011); Davari et al., (2012); Sultana et al., (2015); Shinde et al., (2017)and Latha et al.(2019). The increased phosphorus content might be due to gradual release of nutrients from organic sources thereby increasing soil nutrients along with inorganic source and made available during the growing season (Gautam et al., 2013). Decline in $\mathrm{P}$ content with advancement of crop age was found in all the treatments. Comparing among the different treatments, statistically higher $\mathrm{P}$ content in mustard was observed in $\mathrm{T}_{8}$ showing parity with $\mathrm{T}_{11}$ and $\mathrm{T}_{4}$ followed by $\mathrm{T}_{5}$ which showed similarity with $\mathrm{T}_{6}$ at harvest stage. However, detailed study showed that $\mathrm{P}$ concentration in $\mathrm{T}_{11}, \mathrm{~T}_{8}, \mathrm{~T}_{6}$ and $\mathrm{T}_{4}$ were at par on $30^{\text {th }}, 60^{\text {th }}$ and $90^{\text {th }}$ DAS.

\section{Potassium (K) content}

Perusal of the data in Table 4 presented a progressive decline in $\mathrm{K}$ content with advancement of crop growth in toria was observed in both the years as well as pooled data. The result showed parity with the findings of Shahi et al., (2017) and Latha et al., (2019). The decline in K content might be due to three reasons viz., dilution effect, caused by higher dry matter production, low $\mathrm{K}$ status of soil and fixation of applied $\mathrm{K}$. Irrespective of different growth stages, pooled data revealed that significantly higher $\mathrm{K}$ accumulation in mustard was observed in inorganic and organic $\mathrm{N}$ sources applied singly or in integration of both over control (Nehra and Grewal, 2001; Sultana et al.,
2015; Sohel et al., 2016 and Bairwa and Yadav, 2017). This might be due to release of nutrients from organic sources thereby increasing soil availability along with inorganic source during the growing stage (Gautam et al., 2013). Among the different treatments, significantly higher K content was observed in $\mathrm{T}_{8}$ which was statistically at par with $\mathrm{T}_{11}$ andT $\mathrm{T}_{4}$ on $60^{\text {th }}$, $90^{\text {th }}$ DAS and at harvest.

On the basis of the results, it can be concluded that treatments receiving integrated nitrogen management significantly higher $\mathrm{N}$, $\mathrm{P}$ and $\mathrm{K}$ content over the untreated control. However, with advancement of crop growth progressive decline in $\mathrm{N}, \mathrm{P}$ and $\mathrm{K}$ concentration was observed during both the years of study. Application of integrated nitrogen management improved the macronutrient content of rapeseed (Toria var. M-27). Among the treatments, higher macronutrient accumulation was reported in $\mathrm{T}_{4}$ which is at par with $\mathrm{T}_{6}, \mathrm{~T}_{8}$ and $\mathrm{T}_{11}$.

\section{References}

Anonymous (2017-2018). District wise-areaproduction, Department of Agriculture, Government of Manipur.

Bairwa, S. and Yadav, P.K. (2017). Influence of FYM, Inorganic Fertilizers and Micronutrients on Soil Nutrient Status and Plant Nutrient Contents and their Uptake by African Marigold (Tagetes erecta Linn.). International Journal of Current Microbiology Applied Science, 6(6): 1362-1370.

Chaudhary, M., Singh, B.R., Krogstad, T. and Heim, M. (2011). Release of Copper, Zinc, and Manganese from Rock Powder with Organic Materials Applied to Soils. Communication in Soil Science and Plant Analysis, 42: 2682-2697.

Chidda Singh, 1983. Modern techniques of raising field crops. New Delhi, Oxford 
and IBH publishing Co. Pvt. Ltd. pp. 301.

Davari, M.R., Sharma, S.N. and Mirzakhani, M. (2012). The effect of combinations of organic materials and bio-fertilizers on productivity, grain quality, nutrient uptake and economics in organic farming of wheat. Journal of Organic System, 7(2): 26-35.

Gautam P, Sharma GD, Rana R, Lal B. Effect of integrated nutrient management and spacing on growth parameters, nutrient content and productivity of rice under system of rice intensification. International Journal of Research in Biosciences. 2013; 2(3): 53-59.

Jackson, M.L. Soil Chemical Analysis, Prentice Hall of India Pvt. Ltd., New Delhi, 1973.

Jana, S., Dutta, D., Maity, D. and Bandyopadhyay, P. (2008). Effect of integrated management of organic manure and inorganic $\mathrm{N}$ fertilizer on rice (Oryza sativa) and its residual effect on utera linseed (Linumusitatissimum) and soil fertility. Journal of Crop and Weed, 4(1): 10-14.

Kimmo IJ. Nitrogenous fertilizers and the environment. Proceedings of the regional FADINAP seminar on fertilization and the environment, Chiang Mai, Thailand. 1993; 7-11:113121.

Latha M, Ratna Prasad P, Prasad PRK, Lakshmipathy $\mathrm{R}$ and Srinivasarao $\mathrm{V}$. Effect of integrated nitrogen management on macronutrient content and uptake by rice crop. International Journal of Chemical Studies.2019; 7(1): 1107-1112.

Liu D and Zhu Z. Effect of available phosphorus in paddy soils on phosphorus uptake of rice. Journal of Radioanlytical and Nuclear Chemistry. 1996; 205(2): 235-243.

Nehra, A.S., and Grewal, K.S. (2001).
Influence on Integrated Use of Organic Manures and Inorganic Fertilizers on Soil Fertilizer and Yield of Wheat. Proceeding of International Conference Nature Farming Ecological Balance, Pp. 155.

Nongmeikapam G and Devi NS. Effect of Organic Manures and Humic Acids on Nitrogen Concentration and Yield of Chickpea (JG-16). International Journal of Chemical Studies. 2018; 6(5):27072711.

Pandey N, Verma AK., Anurag and Tripathi RS. Integrated nutrient management in transplanted hybrid rice (Oryza sativa). Indian Journal of Agronomy. 2007; 52(1): 40-42.

Prasad B, Prasad J, Prasad, R. Nutrient management for sustained rice and wheat production in calcareous soil amended with green manures, organic manure and zinc (ENG). Fertilizer News. 1995; 40(3): 39-41.

Rai, S.K., Charak, D. and Bharat, R.(2016). Scenario of Oilseed crops across the globe. Plant Archive, 16 (1): 125-132.

Sarir, M.S., Akhlaq, M., Zeb, A. and Sharif, M. (2005). Comparison of various organic manures with or without chemical fertilizers on the yield and components of maize. Sarhad Journal of Agriculture, 21(2): 237-245.

Shahi, U.P., Deepak Prajapati, Dhyani, B.P., Tomar, S.S., Ashok Kumar and AshishDwivedi. (2017). Effect of balance potassium management on performance of Basmati Rice in ricepotato- maize cropping system of western Uttar Pradesh, India, International Journal of Current Microbiology Applied Science, 4: 147155.

Sharif, M., Ahmad, M., Sarir, M.S. and Khattak, R.A. (2004). Effect of organic and inorganic fertilizers on the yield and yield components of maize. Pakistan 
Journal of Agriculture, 20(1): 11-16.

Shinde, S.E., More, S.S., Gokhale, N.B. and Patil, K.D. (2017). Evaluation of the rice hybrids grown under different INM practices for primary nutrients content and yield under lateritic soil of south Konkan. International Journal of chemical Studies, 5(6): 970-975.

Sinha, S, 2003.Effect of different levels of nitrogen on the growth of rapeseed. Environment Ecology 21, 741 - 774.

Sohel, M.H., Sarker, A., Razzak, Md. A. and Hashem, Md. A. (2016). Integrated use of organic and inorganic fertilizers on the growth and yield of Boro rice (cv. BRRI dhan 29). Journal of Bioscience and Agriculture Research, 10(01): 857865.

Sultana, M.S., Rahman, M.H., Rahman, M.S., Sultana, S. and Paul, A.K. (2015). Effect of integrated use of vermicompost, pressmud and urea on the nutrient content of grain and straw of rice (Hybrid DhanHira 2). International Journal of Scientific Research Publications, 5(11): 22503153.

\section{How to cite this article:}

Wangkhem Herojit Meetei, RK. Kumarjit Singh, A. Herojit Singh, N. Surbala Devi, L. Nabachandra Singh and Gopimohan Singh, N. 2020. Effect of Integrated Nitrogen Management on Macronutrient Content in Toria (Brassica campestris L.var.M-27). Int.J.Curr.Microbiol.App.Sci. 9(11): 379-386. doi: https://doi.org/10.20546/ijcmas.2020.911.046 